\title{
Foraging Behaviour of Three Sympatric Babblers (Family: Timaliidae)
}

\author{
JONATHON JULIANA \& DENCY FLENNY GAWIN*
}

\author{
Faculty of Resource Science and Technology, Universiti Malaysia Sarawak, 94300 Kota Samarahan, Sarawak, \\ Malaysia \\ *Corresponding authors: agdflenny@unimas.my
}

\begin{abstract}
We investigated the foraging ecology of three species of babblers in Kampung Gumbang, Kampung Padang Pan and Dered Krian National Park, Bau. Vegetation in Kampung Gumbang include tall trees, shrubs and patches of kerangas. Dered Kerian National Park consists of mixed dipterocarp forest and limestone forest, which is surrounded by orchards and few villages. In Kampung Padang Pan, the vegetation is a mixed fruit orchard and secondary forest. Foraging data were obtained to compare foraging behaviour in three species. From 133 observations, suspended dead leaves was the most frequently used substrate by the three species. Stachyris maculate showed the most general foraging behavior, and it adopted probing strategy. Cyanoderma erythropterum and Mixnornis gularis obtained food items by gleaning. These three babblers utilize different foraging strategies and substrates, irrespective of their resemblances in other characteristics. C. erythropterum and S. maculate forage mainly among dead and curled, twisted leaves in understory vegetation at significantly different heights. $M$. gularis forages on dead and living leaves and this species can be found abundantly in disturbed forest and plantation or farm habitats. All the three areas were observed never lacked falling leaves and structural complexity required as foraging substrates by those three babbler species. All three babblers occupy different foraging niches, and therefore interspecific competitions among themselves are minimized.
\end{abstract}

Keywords: babbler, foraging strategies, live and dead leaves, niches, substrate,

Copyright: This is an open access article distributed under the terms of the CC-BY-NC-SA (Creative Commons Attribution-NonCommercial-ShareAlike 4.0 International License) which permits unrestricted use, distribution, and reproduction in any medium, for non-commercial purposes, provided the original work of the author(s) is properly cited.

\section{INTRODUCTION}

Babblers (Family: Timaliidae) occupy nearly all tropical and subtropical regions, including in Sundaland. They are one of the main groups of insectivorous birds (Yong et al., 2011). Most babbler species are restricted to the forest interior and have limited distribution. In Borneo, they are comprised of 11 babblers (Phillips \& Phillips, 2011; del Hoyo \& Collar, 2016). They are poor flyers and forage mostly in the understory or near the ground, often in small groups (Smythies, 1999). They mostly have similar bill morphology (slender and either straight or slight decurved) and body size in the range of 11 to $15 \mathrm{~cm}$ in total length. The behavioural ecology of small numbers of babblers in Sunda region has been studied in Peninsular Malaysia and Malaysian Borneo (Styring, Ragai, Zakaria \& Sheldon, 2016; Mansor \& Ramli, 2017).

In this study, we compared the foraging behaviour of three sympatric babblers where they coexist in the secondary, disturbed forest. There are Chestnut-winged babbler Cyanoderma erythropterum, Chestnut-rumped babbler Stachyris maculate, and Striped-tit babbler Mixnornis gularis. These three species are remarkably similar to one another in plumage, voice and social behaviours, and they coexist in secondary, disturbed primary and some plantation forests of Borneo (Smythies, 1999). The C. erythropterum is known to be the greatest generalist, being able to exploit different resources in different environment conditions, while the other two species forage mainly on dead leaves suspended in understory vegetation at significantly different heights (Smythies, 1999; Styring et al., 2016).

We chose the three species as the models for this study as we hypothesized that the three species would occupy different foraging niches. Therefore, interspecific competition among themselves would be minimized and allowing coexistence within the same habitat. To test our hypothesis, we investigated on how the three babblers forage in the wild and use substrate to obtain food materials. In addition, we would examine foraging strategies 
of these three sympatric species in relation to substrates, foraging heights, foraging manoeuvre, and searching behaviours.

\section{MATERIALS \& METHODS}

\section{Study area}

This study was conducted in three sites in Bau from August 2016 to February 2017. The sites were Kampung Gumbang (1 ${ }^{\circ} 16^{\prime} 0^{\prime}$ 'N, $110^{\circ} 3$ '0', E), Kampung Padang Pan ( ${ }^{\circ} 18^{\prime} 47^{\prime}$ 'N, $110^{\circ} 3$ '25' 'E) and Dered Krian National Park, Bau ( $1^{\circ} 23^{\prime} 45^{\prime}$ 'N, $110^{\circ} 8$ '55' 'E) (Figure 1). The sampling period in Kampung Gumbang was 4 days, Dered Kerian 5 days and Kampung Padang Pan 4 days. The Kampung Gumbang sampling site consists of lowland dipterocarp forest, kerangas forest and a few patches of limestone shrubs with stream disappears through the permeable limestones. The Kampung Padang Pan site consists of mixed dipterocarp forest, fruit orchard and secondary forest. As for the Dered Krian National Park, it consists of both mixed dipterocarp forest and limestone forests that grow on the limestone hill areas, which is surrounded by orchards and few small villages. Selection of these three sites, allowed plentiful opportunities to observe babblers foraging under a variety of habitat environments.

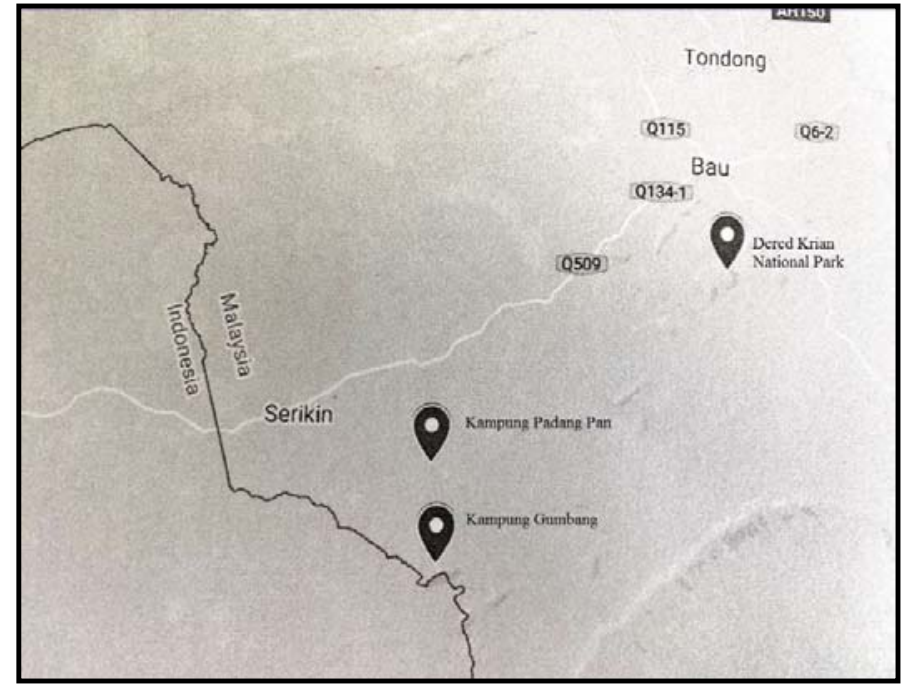

Figure 1. Three sampling sites in Bau; Kampung Padang Pan, Kampung Gumbang and Dered Krian National Park.

Data for habitats are comparable among the three sites by integrating variables such as percentage of canopy cover $(\%)$ and leaf litter depth $(\mathrm{cm})$. Percentage of canopy cover was estimated by using a spherical densiometer that uses a convex mirror with a grid of 24 squares. Canopy cover was calculated from the number of squares on the mirror filled with vegetation. Leaf litter depth was recorded in $2 \times 2$ m quadrats which placed on the ground where the birds gathered their food items. This was done at each point at each sampling site. The leaf litter depth was measured with a $30 \mathrm{~cm}$ ruler at the four corners of each quadrate.

\section{Foraging data}

Birds were surveyed along a 1,000 m transect trail for each sampling site (Figure 2-4). Points were spaced at the minimum distance of $50 \mathrm{~m}$ apart along transect (20-point counts for each 1,000 m transect trail). This was to prevent spatial pseudo-replication (Melo \& Guilherme, 2016).

Observations using a Nikon 8 x 42 binocular, were performed for four days in each sampling site. Foraging observations started from $0700 \mathrm{~h}$ to $1100 \mathrm{~h}$, when birds were actively searching for foods and light was enough for observation. At each point, a 5-minute survey was conducted using distance sampling. Babblers were detected either by sight or sound. Foraging observations were recorded once per individual per species per transect per 


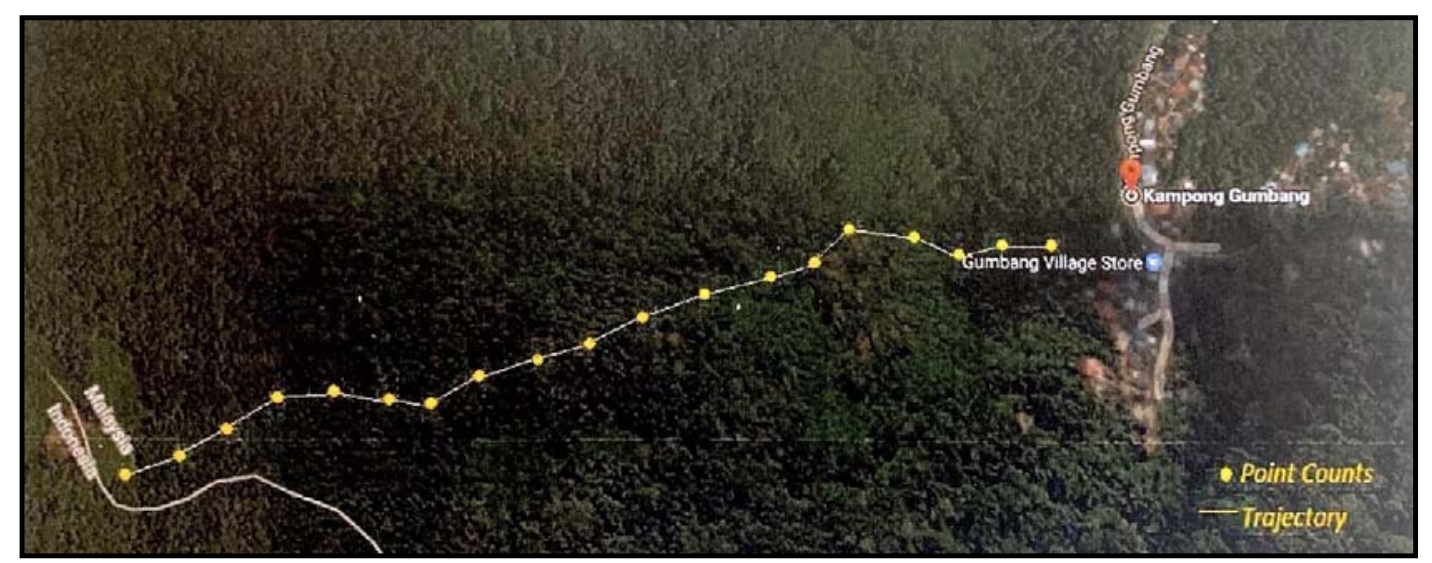

Figure 2. Point counts and the trail in Kampung Gumbang.

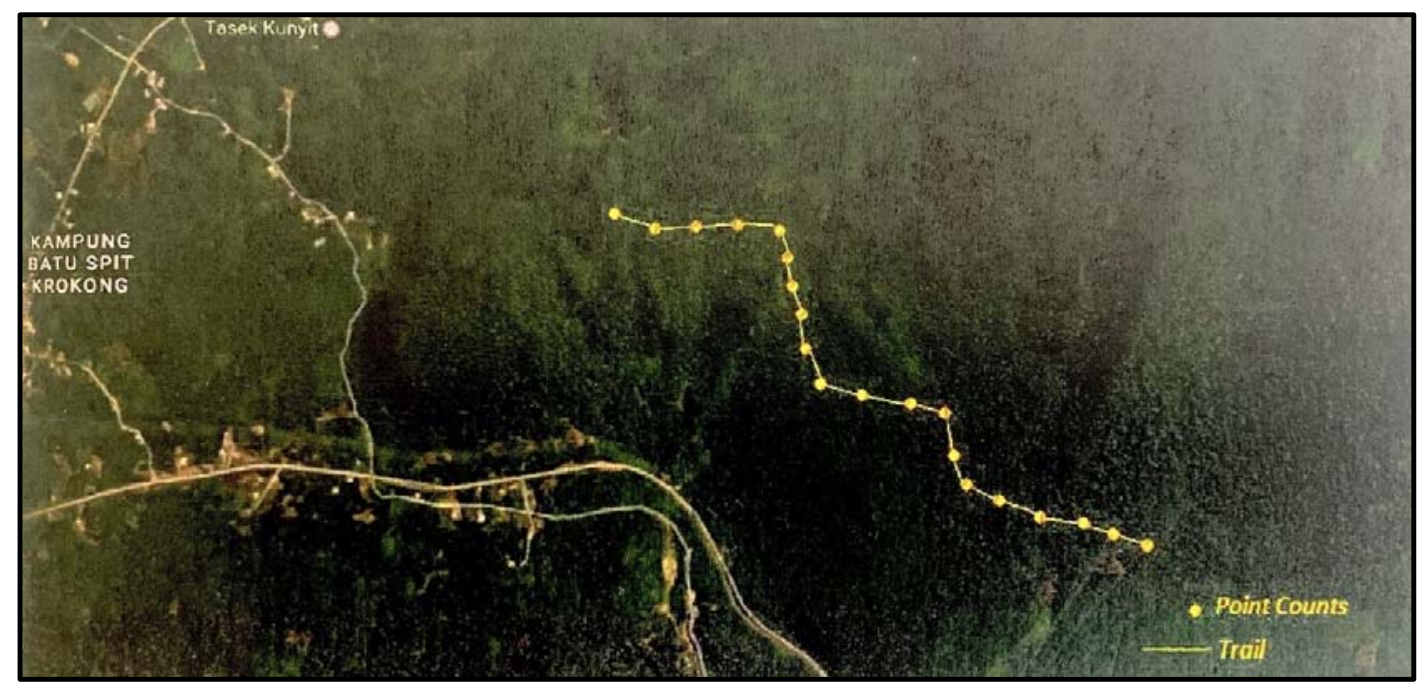

Figure 3. Point count and the trail in Dered National Park.

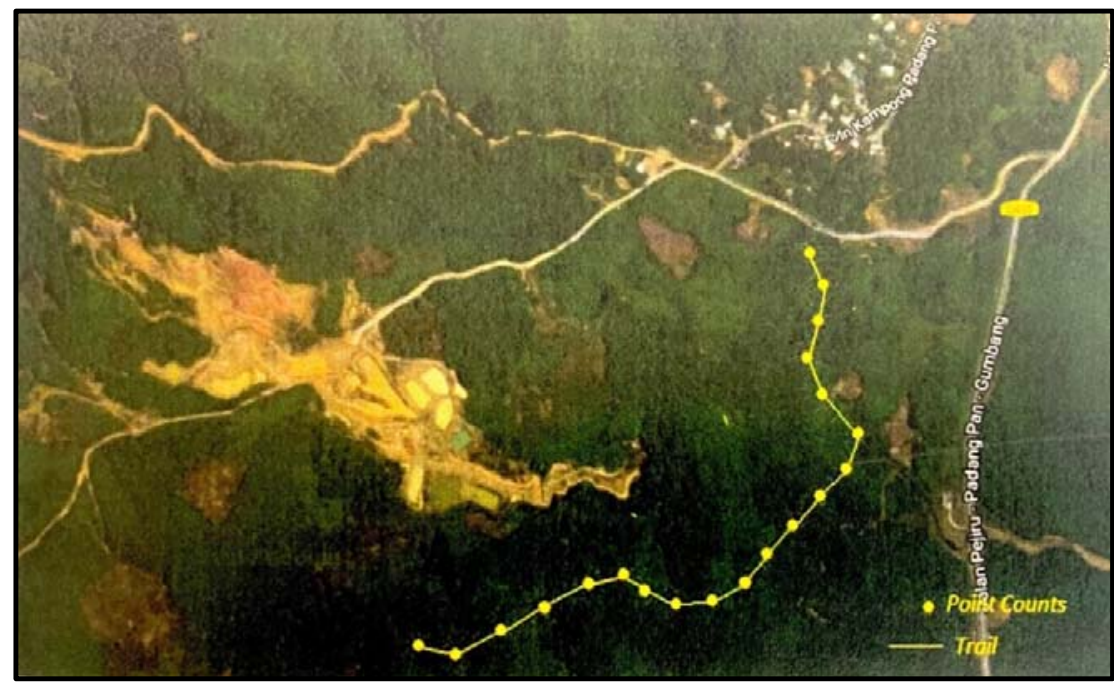

Figure 4. Point counts and the trail in Kampung Padang Pan. 
survey (Styring et al., 2016). For every individual, it was observed until it has successfully obtained a food item (determined either by the observation of the food item and by eating behaviour). Following Morisson (1984), at least 30 independent observations were conducted for each babbler species to accurately represent the observed foraging behaviour.

In this study, foraging data collected consisted: (1) foraging height above the ground, (2) foraging substrate, (3) foraging maneuver, and (4) searching behaviour.

Foraging height: A foraging height is the level from which a food item is obtained by the birds. At each point count, a Suunto clinometer was used to estimate the foraging height $(\mathrm{m})$ of each bird.

Foraging substrate: A foraging substrate is an underlying substance or layer (microhabitat) form which food items are taken by the birds. These substrates consist of dead leaf (suspended or on ground), live leaf, liana, rattan, palm, dead wood (dead liana/ rattan, dead branch), loose bark. In this study, the height of substrate from the floor was measured using a measuring tape (meter).

Foraging manoeuvre: The foraging manoeuvre refers to few methods that are taken (foraging) by birds (Remsen \& Robinson, 1990). The babblers adopt few types of manoeuvre such as: (1) glean - to pick food items from a nearby substrate, that can be reached without full extension of legs or necks, and no involvement of acrobatic movements, (2) reach/stretch - to extend completely the legs or neck upwards, outwards, or downwards to reach food items. (3) hang - to use legs and toes to hang the body below the feet to reach food items that cannot be reached from any other perched position; can be categorized into four positions (hang-up, hang-down, hangsideways and hang-upside-down, (4) lunge - quick movement rather than flight are applied by birds to approach and capture preys that are beyond the range of "reach", (5) probe - to insert the bill into cracks or holes in hard substrate or straight into softer substrates such as moss or mud to capture hidden foods, (6) peck - to drive the bill against the substrate to remove some of the exterior of the substrate to reach the hidden foods, (7) flake - to brush aside loose substrate with sideways using the bill in sweeping motions, (8) sally - to fly from a perch to foraging a food item and then return to a perch.

Searching behaviour: Searching behaviour refers to movements used by birds to search for food or substrates that hide food. The searching activities will end once food or food-hiding substrates are spotted and foraged (Remsen and Robinson, 1990). Searching methods can be categorized as follows: (1) hop - similar to jump, but starts off with one leg, and lands with both legs, (2) jump (leg-powered jumps using both legs that cover more space than the typical hop), (3) climb - a perching technique which birds walk from bottom to top while their claws grasp on the branches, (4) glide - birds spread their wings and fall from branches to another branches, (5) flutter - the wings are flapped before taking off to another branches, and (6) fly - birds take off from a branch and flap their wings to reach another branch.

\section{Statistical analyses}

To compare foraging behavior among the three babbler species and to visualize substrate preferences, correspondence analysis was performed on substrates, foraging maneuvers, and searching behavior in SPSS version 25 (2017). This type of analysis is principally effective for showing variation in foraging data (Miles, 1990; Naoki, 2007). Foraging height was compared among species using Analysis of Variance (ANOVA), and post-host comparison were made using Tukey's Honestly Significant Difference in PAST 3 software (Hammer, et al., 2001). All obtained values were presented as mean \pm standard deviation (SD).

\section{RESULTS}

\section{Habitats}

Two habitat variables were compared among the three sites: percentage of canopy cover and leaf litter depth. Habitat variables showed less variation among the three sampling sites. Percentage of canopy cover in Dered Krian National Park $($ mean $=85.65 \pm 14.89 \%)$ was higher than Kampung Gumbang $($ mean $=80.25 \pm 15.15 \%)$ and 
Kampung Padang Pan (mean $=77.05 \pm 6.0 \%$ ). As for leaf litter depth, Kampung Padang Pan recorded higher $($ mean $=5.55 \pm 1.90 \mathrm{~cm})$ than Dered Krian National Park $($ mean $=4.975 \pm 1.32 \mathrm{~cm})$ and Kampung Gumbang (mean $=4.11 \pm 1.51 \mathrm{~cm})$.

\section{Bird occurrence}

A total of 133 observations belonging to the three babbler species were recorded in the three studies areas. Mixnornis gularis, was the most observed in the study areas with a total number of 56 observations (17 in Kampung Gumbang, 15 in Dered Krian, 24 in Kampung Padang Pan). This species usually travels in a flock, or together with other species such as flowerpeckers and sunbirds. Cyanoderma erythropterum is the second most sighted with a total number of 42 observations (13 in Kampung Gumbang, 8 in Dered Krian, 21 in Kampung Padang Pan), followed by S. maculate with 35 observations (7 in Kampung Gumbang, 6 in Dered Krian, 22 in Kampung Padang Pan).

Foraging ecology

Most of the observed birds foraged over a wide variety of substrates (Figure 5; Supplemental Table S1) but suspended dead leaves was the most frequently used substrate by the three species. Live green leaves were the second-most used substrate. Correspondence analysis of substrate preference resulted in 2 dimensions (singular value dimension $1=0.56$; dimension $2=0.182$ ) in the substrate data (Figure 6). Stachyris maculata showed the most general foraging behaviour, feeding on dead leaf (54\% of the observation), dead branch (23\%), and liana $(6 \%)$. Meanwhile, the other two species foraged on two substrate types. Cyanoderma erythropterum foraged mainly on suspended dead leaf $(60 \%)$ and liana (7\%). However, S. maculata and C. erythropterum foraged at different height (Figure 7), with S. maculata higher $(10.5 \pm 1.08 \mathrm{~m})$ than C. erythropterum $(5.7 \pm 0.50 \mathrm{~m})$. Mixnornis gularis, foraged in dead leaf (20\%), and on live leaf (57\%) and stayed almost lower to the ground (4.9 $\pm 0.90 \mathrm{~m})$.

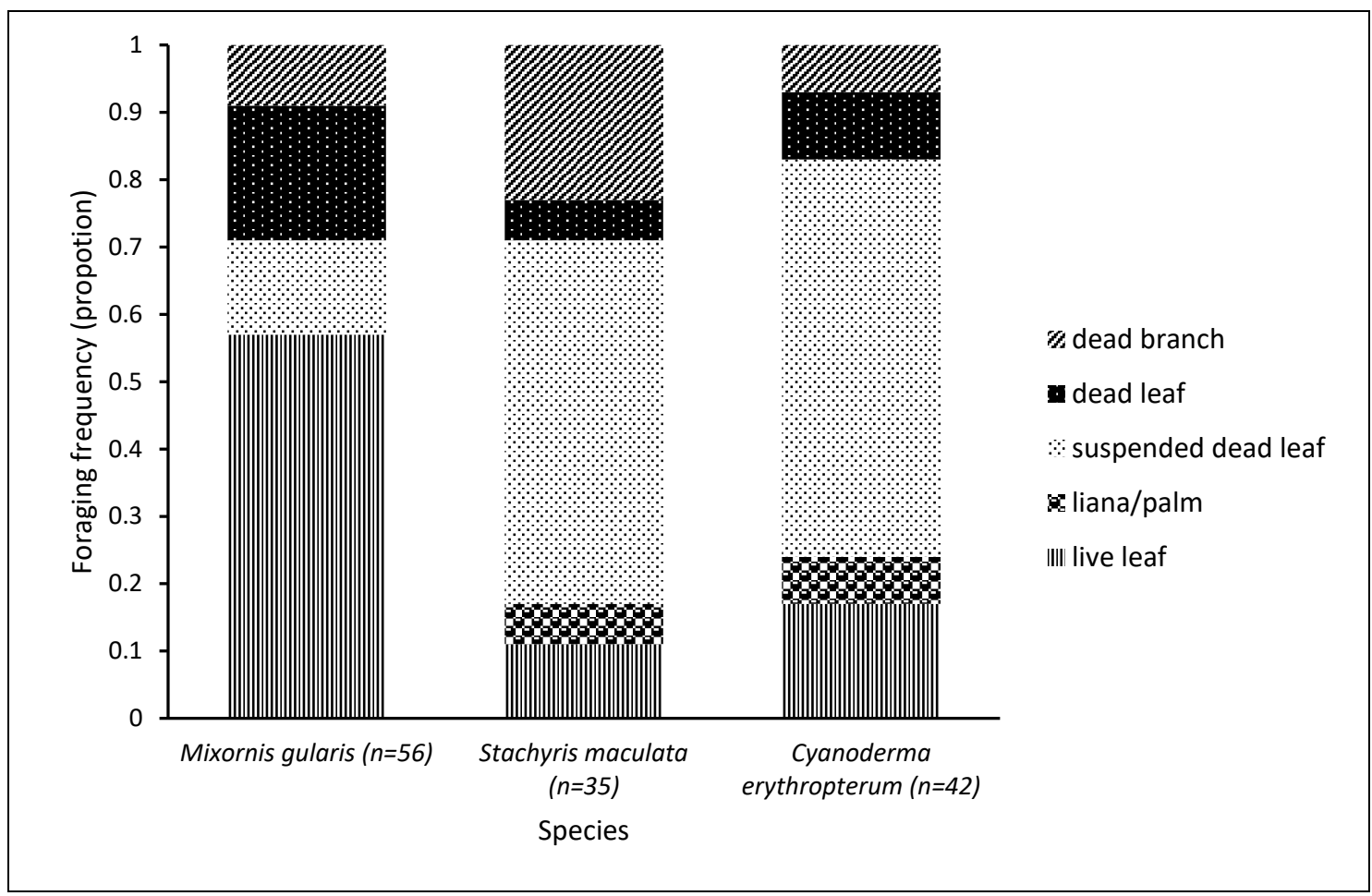

Figure 5. A stacked bar chart of proportional foraging frequency on specified substrates by three babbler species from the three studied sites in Bau. 


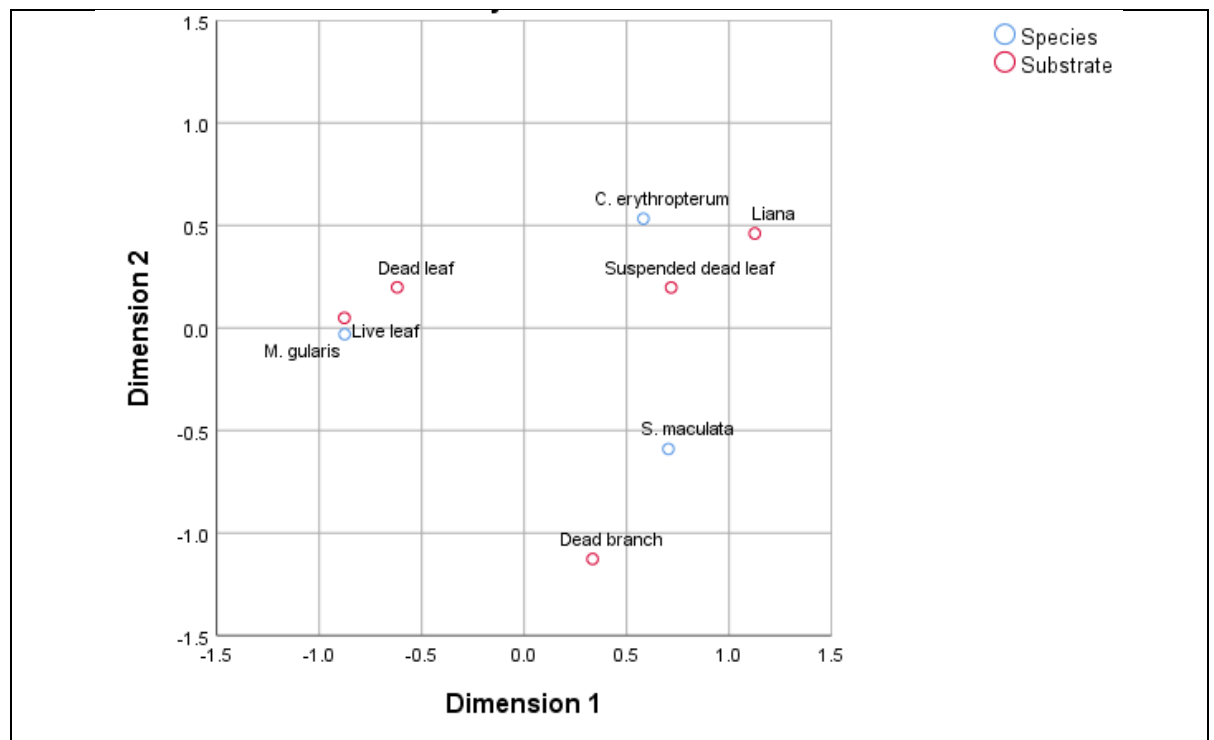

Figure 6. Correspondence analysis of substrate preference of three species of babblers.

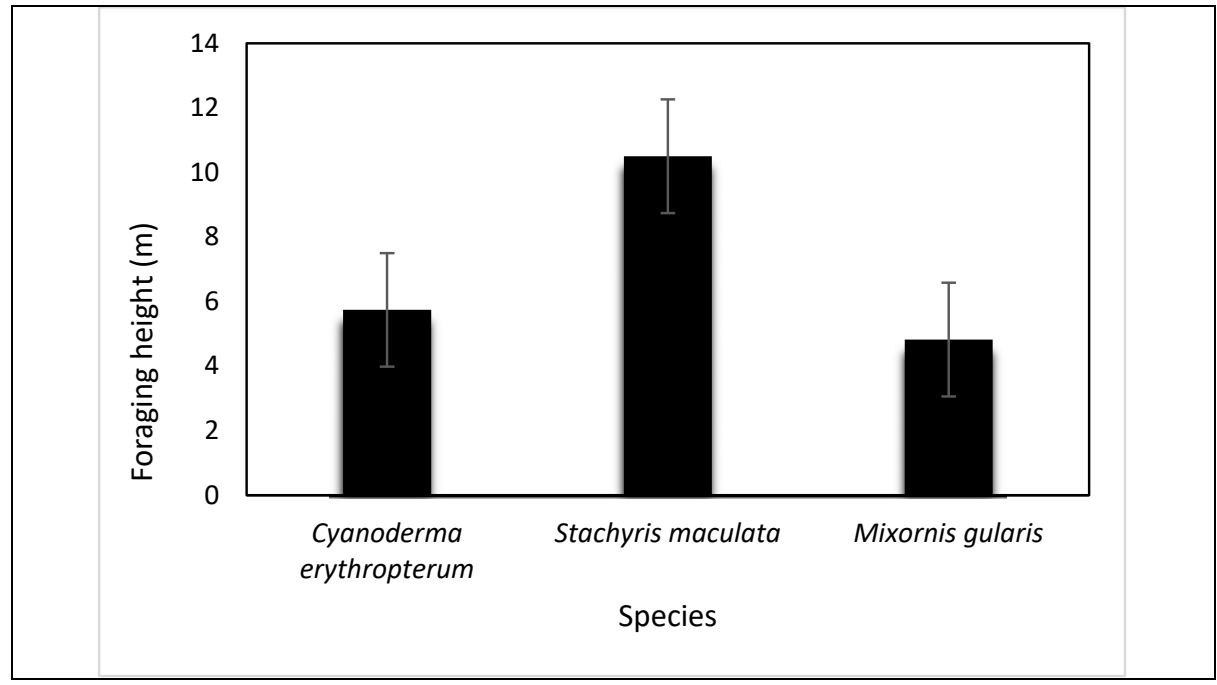

Figure 7. Average foraging height of 3 species of babblers. Error bars represent $95 \%$ confidence intervals. ANOVA results $\left(\mathrm{F}_{2,130}=511.6, P<0.001\right)$, Tukey's HSD comparisons indicate that $S$. maculata forages at significantly greater heights than the other two species $(\mathrm{P}<0.001$ in all cases $)$.

Correspondence analysis of foraging manoeuvres resulted in two dimensions explained $67 \%$ of the total inertia (Figure 8; Supplemental Table S2). Of the species that foraged on suspended dead leaves and dead leaves, $S$. maculate probed significantly more than other species (53\% of observation) and obtained food items by pecking (35\%) and hanging down (11\%). Cyanoderma erythropterum obtained food items frequently by gleaning (46\%), hanging (42\%) and pecking (12\%). Mixnornis gularis frequently gleaned (59\%), but also pecked (30\%) and hung down $(10 \%)$.

Finally, correspondence analysis of searching behaviours resulted in two dimensions explained $35 \%$ of the total inertia (Figure 9; Supplemental Table S3). Cyanoderma erythropterum was observed to hop (54\% of observation) and fly (40\%) in searching for foods in dead leaf, while S. maculate was observed to jump (35\%) and fly (39\%). Mixnornis gularis adopted flutter (7\%), fly (38\%) and jump (29\%) to find foods. 


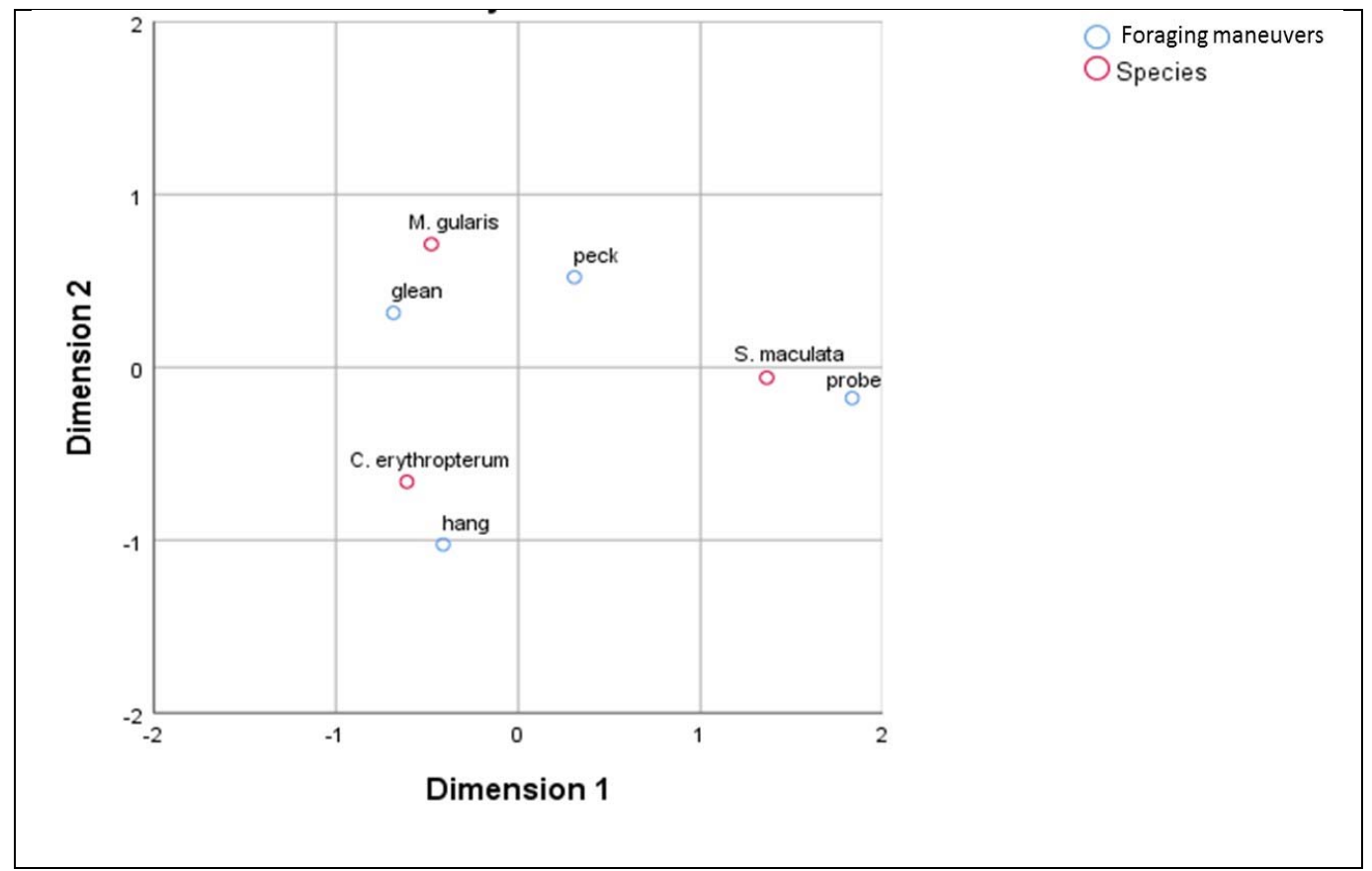

Figure 8. Correspondence analysis of foraging maneuvers in three species of babblers.

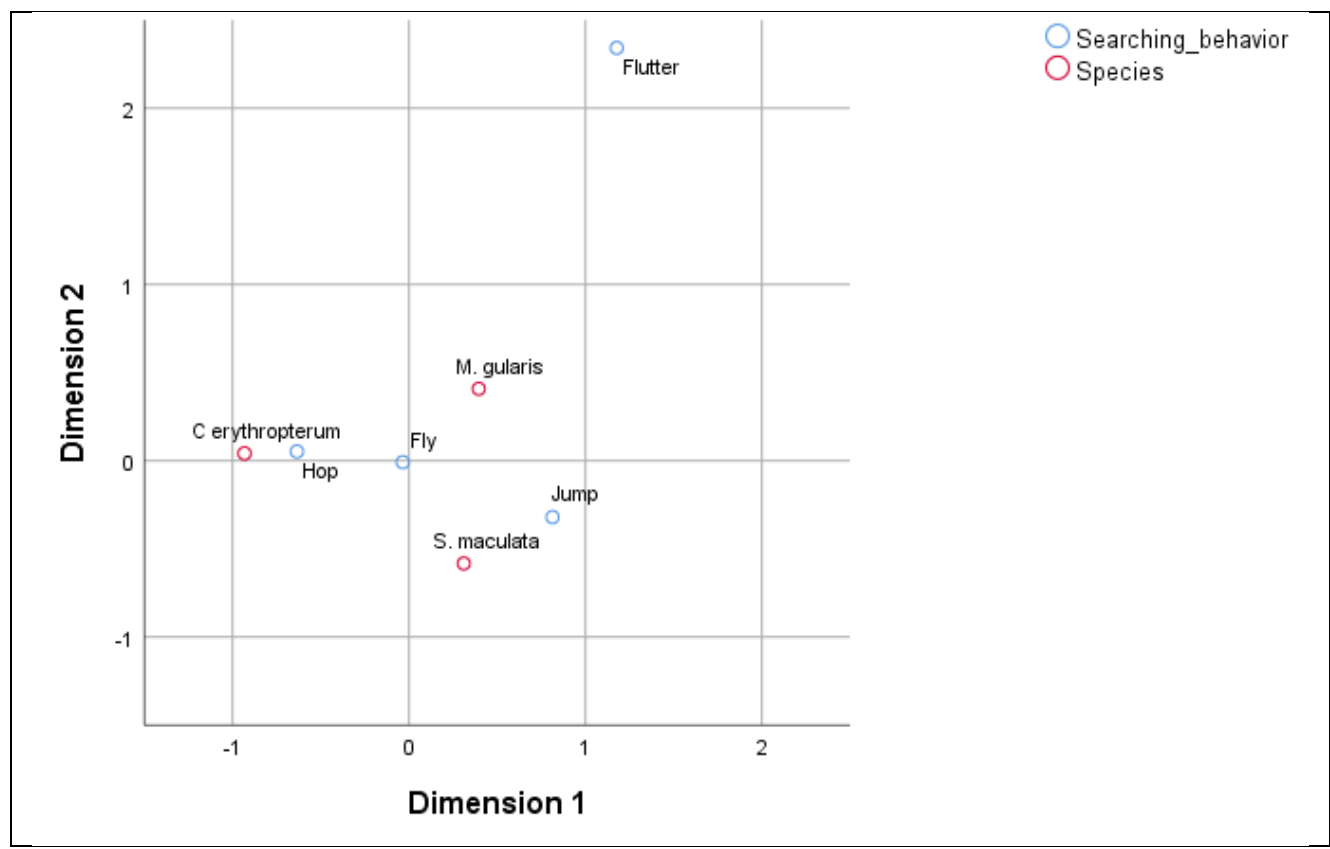

Figure 9. Correspondence analysis of searching behaviours in three species of babblers.

\section{DISCUSSION}

The three babblers compared in this study, utilize largely different foraging strategies and substrates, regardless of their similarities in other characteristics. Cyanoderma erythropterum and S. maculata seem to focus on dead and curled, twisted leaves, which serve as hiding and nesting sites for arthropods. Cyanoderma erythropterum and S. maculata pursuit leaves suspended in liana tangles, plus S. maculata focusing on sites higher in the 
understory than C. erythropterum. These two babblers are not interested to forage among the living leaves as the concentration of arthropod prey is low (Leme, 2001). However, dead leaves are more unevenly distributed and seemingly need more time and energy to search and extract food items from than green leaves (Rosenberg, 1993).

Due to their dead-leaf strategy, C. erythropterum and S. maculata occur in abundance in regenerating logged forest and older plantation groves, where greater light access helps the growth of a thicker understory (Sheldon, Strying \& Hosner, 2010; Styring et al., 2011; Styring et al. 2016), and where leaf litter is expected to be sizable (Stratford \& Stouffer, 2013; Styring et al., 2016). Within these habitats, chances for capture of falling leaves by understory vegetation is boosted by the plentiful development of lianas, vines, and shrubs (DeWalt, Maliakal \& Denslow, 2003; DeWalt, Ickes, Nilus, Harms \& Burslem, 2006; Styring et al., 2016). In addition, C. erythropterum and S. maculata can also be found in habitats such as pole forest growing on ultrabasic soils, bamboo thickets and river edges (Sheldon et al. 2010; Styring et al., 2016). In contrast, these two species are not as abundant in actively managed habitats in which the understory is stripped, such as oil palm, trimmed rubber, young industrial tree groves, and repaired logged forests (Sheldon et al. 2010; Styring et al., 2016). This could be explained that the understory in mature forest is more open which causing suitable microhabitats to be more widely spaced, and that competition from insectivorous birds is expected to be greater (Styring et al., 2016).

Mixornis gularis was considered a generalist of the group. The species search for food items on dead and living leaves (Figure 5). It was common in the largest assortment of disturbed forest and plantation or farm habitats. (Smythies 1999; Mansor \& Mohd. Sah, 2012). The foraging patterns of M. gularis in this study is similar as the results obtained by Mansor and Mohd. Sah (2012). Both found M. gularis to be a leaf gleaner, focusing on the underside of living leaves, while C. erythropterum foraged on dead branches and curled up dead leaves. In addition, they observed that both species occurred mainly in forest of intermediate foliage density. The foraging height of C. erythropterum in their study was similar as the foraging height in our study which was between $0 \mathrm{~m}$ to $5 \mathrm{~m}$. However, in their study, foraging height of $M$. gularis was at $>6 \mathrm{~m}$, while in our study the foraging height were between $0 \mathrm{~m}$ to $5 \mathrm{~m}$.

All three studied areas consist almost similar vegetations. Besides, habitat variables (e.g. canopy cover and leaf litter-depth) showed less variation among the three areas. Canopy cover percentages in all three studied areas are above $70 \%$. This high percentage of canopy cover reveals that many trees in the areas can be as high as $60 \mathrm{~m}$ which eliminate most light from the forest floor. However, a number of plants especially adapted to low-light do grow on the forest floor. We observed all the three areas never lacked falling leaves and structural complexity required as foraging substrates by those three babbler species. A habitat that lacks foraging and nesting substrates will result in reduction of bird species diversity (Sheldon et al., 2010).

\section{CONCLUSION}

From this study, each babbler species adopts different foraging strategies relative to substrates used, foraging height, foraging manoeuvre, and searching behaviours. They occupy different foraging niches, and therefore interspecific competitions among themselves are minimized and they coexist within the same habitat.

\section{ACKNOWLEDGEMENTS}

We would like to thank you to the staff of Faculty of Resource Science and Technology, Universiti Malaysia Sarawak for providing assistance. We also like to Madam Roberta Chaya Tawie anak Tingga and Dr Mohamad Fizl Sidq Ramji for providing ideas and guidance on conducting this project.

\section{REFERENCES}

del Hoyo, J., \& Collar, N. J. (2016). HBW and BirdLife International Illustrated Checklist of the Birds of the World. Volume 2: Passerines. Lynx Edicions and BirdLife International, Barcelona, Spain and Cambridge, UK. 
Trends in Undergraduate Research (2020) 3(2): a26-34

https://doi.org/10.33736/tur.2138.2020

DeWalt, S. J., Ickes, K., Nilus, R., Harms, K. E., \& Burslem, D. F. (2006). Liana habitat associations and community structure in a Bornean lowland tropical forest. Plant Ecology, 186, 203-216.

DeWalt, S. J., Maliakal, S. K., \& Denslow, J. S. (2003). Changes in vegetation structure and composition along a tropical forest chronosequence: implications for wildlife. Forest Ecology and Management, 182(1), 139151.

Hammer, Ø., Harper, D. A. T., \& Ryan P. D. (2001). PAST: Paleontological Statistics Software Package for Education and Data Analysis. Palaeontologia Electronica, 4(1), 9pp.

Leme, A. (2001). Foraging patterns and resource use in four sympatric species of antwrens. Journal of Field Ornithology, 72, 221-227.

Mansor, M. S., \& Mohd. Sah, S. A. (2012). Foraging patterns reveal niche separation in tropical insectivorous birds. Acta Ornithologica, 47, 27-36.

Mansor, M. S., \& Ramli, R. (2017). Foraging niche segregation in Malaysia babblers (Family: Timaliidae). Plos One, 12(3), e0172836. doi:10.1371/Journal.pone.0172836.

Melo, T. N., \& Guilherme, E. (2016). The foraging behavior of the Large-headed Flatbill, Ramphotrigon megacephalum and the Dusky-tailed Flatbill, Ramphotrigon fuscicauda (Aves: Tyrannidae). Zoologia, 33(6), e20160104.

Miles, D. B. (1990). A comparison of three multivariate statistical techniques for the analysis of avian foraging data. Studies in Avian Biology, 13, 295-308.

Morrison, M. L. (1984). Influence of sample size and sampling design on analysis of avian foraging behavior. The Condor, 86, 146-150.

Naoki, K. (2007). Arthropod resource partitioning among omnivorous Tanagers (Tangara spp.) in Western Ecuador. The Auk, 124, 197-209.

Phillips, Q., \& Phillips, K. (2011). Phillips’ Field Guide to the Birds of Borneo. Oxford, England. John Beaufoy Publishing Ltd. Pp 370.

Remsen, J. V. Jr., \& Robinson, S. K. (1990). A classification scheme for foraging behavior of birds in terrestrial habitats. Studies in Avian Biology, 13, 144-160.

Rosenberg, K. V. (1993). Diet selection in Amazonian antwrens: consequences of substrate specialization. The Auk, 110, 36-375.

Sheldon, F. H., Styring, A. R., \& Hosner, P. A. (2010). Bird species richness in a Bornean exotic tree plantation: a long-term perspective. Biological Conservation, 143(2), 399-407.

Smythies, B. E. (1999). The birds of Borneo. Kota Kinabalu, Sabah: Natural History Publications.

Stratford, J. A., \& Stouffer, P. C. (2013). Microhabitat associations of terrestrial insectivorous birds in Amazonian rainforest and second-growth forests. Journal of Field Ornithology, 84, 1-12.

Styring, A. R., Ragai, R., Unggang, J., Stuebing, R., Hosner, P. A., \& Sheldon, F. H. (2011). Bird community assembly in Bornean industrial tree plantations: effects of forest age and structure. Forest Ecology and Management, 261(3), 531-544.

Styring, A. R., Ragai, R., Zakaria, M., \& Sheldon, F. H. (2016). Foraging ecology and occurrence of 7 sympatric babbler species (Timaliidae) in the lowland rainforest of Borneo and Peninsular Malaysia. Current Zoology, 62(4), 345-355.

Yong, D. L., Qie, L., Sodhi, N. S., Koh, L. P., Peh, K. S., Lee, T. M., Lim, H. C., \& Lim, S. L. (2011). Do insectivorous bird communities decline on land-bridge forest islands in Peninsular Malaysia? Journal of Tropical Ecology, 27(1), 1-14. 